\title{
Dechloromonas hortensis sp. nov. and strain ASK-1, two novel (per)chlorate-reducing bacteria, and taxonomic description of strain GR-1
}

Correspondence
Servé W. M. Kengen
serve.kengen@wur.nl

The occurrence of perchlorate and chlorate in natural environments is due mainly to human activities. Chlorate is used as a herbicide, as a catalyst in matches and for onsite production of chlorine dioxide $\left(\mathrm{ClO}_{2}\right)$, a bleaching agent employed in the paper and pulp industries. Perchlorate is used

Published online ahead of print on 22 July 2005 as DOI 10.1099/ ijs.0.63404-0.

The GenBank/EMBL/DDBJ accession numbers of the 16S rRNA gene sequences of strains ASK-1, MA-1 and GR-1 are AY277620, AY277621 and AY277622.

Photographs of colonies and cell extracts of $P$. chloritidismutans and strain ASK-1 and a transmission electron micrograph of cells of strain GR-1 are available as supplementary material in IJSEM Online. as rocket propellant in the defence and aerospace industries. In the United States, discharge of perchlorate-containing waste streams has been identified as the major source of perchlorate contamination in drinking water supplies (Renner, 1998; US Environmental Protection Agency, 2000). Chlorate and perchlorate are highly soluble and chemically stable under environmental conditions (Urbansky, 2002). Remediation strategies by chemical reduction or by adsorption to activated carbon are either too slow or incomplete (Urbansky, 1998). Recent research has shown that bioremediation may be the most economically feasible, fastest and easiest means of treating (per)chlorate-contaminated sites and water sources (Coates \& Achenbach, 2004). (Per)chlorate-reducing bacteria are able to perform a 
complete reduction of (per)chlorate to chloride using various carbon compounds or hydrogen as electron donor. (Per)chlorate is reduced to chlorite by a (per)chlorate reductase [EC 1.97.1.1] (Kengen et al., 1999) and subsequently chlorite is converted to chloride and oxygen by a chlorite dismutase [EC 1.13.11.49] (van Ginkel et al., 1996).

(Per)chlorate-reducing bacteria are widespread in nature (van Ginkel et al., 1995; Coates et al., 1999; Wu et al., 2001) and have been isolated from chlorate- and perchloratecontaminated sites. For example, 'Acinetobacter thermotoleranticus' was isolated from a match-factory waste stream (Stepanyuk et al., 1992). Previous studies on the ubiquity and diversity of (per)chlorate-reducing bacteria resulted in the description of Dechloromonas and Dechlorosoma species; to date, these appear to be the dominant (per)chloratereducing bacteria in the environment (Coates et al., 1999). (Per)chlorate-reducing activity has been observed not only in chlorate- or perchlorate-polluted samples, but also in pristine sediments and soils (van Ginkel et al., 1995; Coates et al., 1999; Wu et al., 2001). However, no isolate from a pristine setting has been characterized or deposited in culture collections. Here, we describe two novel strains, MA-1 ${ }^{\mathrm{T}}$ and ASK-1, isolated, respectively, from garden soil and the sludge of a bioreactor treating a bromate-/chlorate-polluted waste stream. We also performed phylogenetic analysis on a third, previously described strain, strain GR-1 (Rikken et al., 1996). Strain GR-1 was included here because it represents one of the best studied (per)chlorate-reducing bacteria, especially concerning the biochemistry of the reduction process. However, a taxonomic description was as yet lacking.

Enrichment and cultivation of strains MA- $1^{\mathrm{T}}$ and ASK-1 were performed in anoxic medium as described previously for Pseudomonas chloritidismutans DSM $13592^{\mathrm{T}}$ (Wolterink et al., 2002) with the following modifications: The gas phase used was $\mathrm{N}_{2} / \mathrm{CO}_{2}(80: 20)$ and, instead of $0 \cdot 5 \mathrm{~g} \mathrm{Na}_{2} \mathrm{~S}, 0 \cdot 2 \mathrm{~g}$ $\mathrm{Na}_{2} \mathrm{SO}_{4}$ was used as a sulfur source (Wolterink et al., 2002). For the isolation of both strains, chlorate $(10 \mathrm{mM})$ and acetate $(10 \mathrm{mM})$ were used as electron acceptor and electron donor, respectively. Batch cultures were incubated in the dark at $30^{\circ} \mathrm{C}, \mathrm{pH} 7 \cdot 2$, on an orbital shaker set at 100 r.p.m. For enrichment and isolation of strain ASK-1, sludge was taken from an anaerobic bioreactor treating chlorate-/bromate-polluted wastewater. Samples from this sludge were also used to isolate $P$. chloritidismutans DSM $13592^{\mathrm{T}}$ (Wolterink et al., 2002). Pure cultures of strain ASK1 were obtained following repeated application of the rolltube dilution method (Hungate, 1969). To isolate strain $\mathrm{MA}-1^{\mathrm{T}}$, approximately $2 \mathrm{~g}$ garden soil was added to $40 \mathrm{ml}$ of the medium described above. Strain MA- $1^{\mathrm{T}}$ was isolated to purity on aerobically incubated nutrient agar plates. Enrichment cultures were monitored for chlorate reduction by analysing the growth medium by HPLC as described previously (Scholten \& Stams, 1995). Oxygen levels were measured by GC as described by Stams et al. (1993). Substrates were added from $0 \cdot 8 \mathrm{M}$ stock solutions to give final concentrations of $10 \mathrm{mM}$. Use of the following electron donors $(10 \mathrm{mM})$ was evaluated with chlorate $(10 \mathrm{mM})$ as electron acceptor: acetate, propionate, glucose, maltose, mannitol, malate, lactate, arabinose, hydrogen, glycine, glycerol, formate, gluconate, ethanol, starch, citrate and succinate. The following electron acceptors $(10 \mathrm{mM})$ were tested with acetate $(10 \mathrm{mM})$ as electron donor: perchlorate, chlorate, chlorite, nitrate, bromate, sulfate and oxygen. All anions were supplied as sodium salts. For strain MA- $1^{\mathrm{T}}$, $\mathrm{Fe}^{3+}$ reduction to $\mathrm{Fe}^{2+}\left[\mathrm{Fe}^{3+}\right.$ applied as iron(III) citrate] was monitored spectrophotometrically at $562 \mathrm{~nm}$ using the ferrozine assay described by Lovley \& Phillips (1987). Different medium $\mathrm{pH}$ values were obtained by changing the $\mathrm{CO}_{2}$ concentration appropriately in the gas phase, calculated using the Henderson-Hasselbach equation (Wolterink et al., 2002). Growth was followed at the following temperatures: $10,20,30,37$ and $50^{\circ} \mathrm{C}$. Strain GR-1 (=DSM 11199) was grown in a medium described before (Rikken et al., 1996) with modifications described by Kengen et al. (1999), P. chloritidismutans DSM $13592^{\mathrm{T}}$ was grown in the medium described by Wolterink et al. (2002) and Pseudomonas stutzeri DSM 50227 was grown in the medium described by Matsubara et al. (1982) as modified by Coyle et al. (1985). Gram-type was determined by Gram staining using the protocol described by Plugge et al. (2000).

Almost full-length (approx. 95\%) 16S rRNA gene sequences for strains ASK-1, MA- $1^{\mathrm{T}}$ and GR-1 were determined at the DSMZ by direct sequencing of PCR-amplified 16S rRNA genes as described by Rainey et al. (1996). 16S rRNA gene sequences were analysed using ARB software (Ludwig \& Strunk, 1996). 16S rRNA gene sequences of the three strains were compared to the following type strains: $P$. chloritidismutans DSM $13592^{\mathrm{T}}$ (GenBank accession no. AY017341), Dechloromonas agitata DSM $13637^{\mathrm{T}}$ (AF047462) and Azospira oryzae LMG 9096 ${ }^{\mathrm{T}}$ (AF011347). Also, P. stutzeri DSM 50227 (GenBank accession no. U26415), closely related to $P$. chloritidismutans DSM $13592^{\mathrm{T}}$ (Wolterink et al., 2002), and Dechlorosoma suillum DSM $13638^{\mathrm{T}}$ (AF170348), closely related to Azospira oryzae LMG $9096^{\mathrm{T}}$, were used for 16S rRNA gene sequence comparison. Genomic DNA was isolated by chromatography on hydroxyapatite after the method of Cashion et al. (1977). DNADNA hybridization between strain GR-1 and Dechlorosoma suillum DSM $13638^{\mathrm{T}}$, strain MA-1 ${ }^{\mathrm{T}}$ and Dechloromonas agitata DSM $13637^{\mathrm{T}}$ and strain ASK-1 and P. chloritidismutans DSM $13592^{\mathrm{T}}$ was carried out as described by De Ley et al. (1970), as modified by Huß et al. (1983) and Escara \& Hutton (1980). Renaturation rates were computed with the TRANSFER.BAS program (Jahnke, 1992). The $\mathrm{G}+\mathrm{C}$ content of strain MA- $1^{\mathrm{T}}$ was determined using the HPLC method described by Mesbah et al. (1989); unmethylated lambda DNA (Sigma) was used as the standard. DNA-DNA hybridization studies as well as $\mathrm{G}+\mathrm{C}$ analyses were conducted at the DSMZ.

Cell extracts were prepared in an anaerobic glovebox containing $\mathrm{H}_{2} / \mathrm{N}_{2}$ (4 : 96) gas (Wolterink et al., 2002). Oxyanion reductase activities were determined spectrophotometrically, 
as described previously by Kengen et al. (1999), by monitoring the oxidation of reduced methyl viologen at $578 \mathrm{~nm}$ and $30^{\circ} \mathrm{C}$. Chlorite dismutase activity was determined as described by Wolterink et al. (2002), by measuring $\mathrm{O}_{2}$ production with a Clark-type oxygen electrode (Yellow Springs Instruments). We define $1 \mathrm{U}$ activity as the amount of enzyme required to convert $1 \mu \mathrm{mol}$ chlorite (or chlorate, bromate, nitrate) $\mathrm{min}^{-1}$. The protein content of the cell extracts was determined according to the method of Bradford (1976) with BSA as the standard.

Cells of strain GR-1 were prepared for electron microscopy by fixation in $4 \%$ formaldehyde in $0.01 \mathrm{M}$ PBS

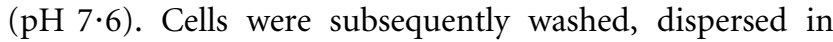
PBS and adsorbed to glow-discharged, carbon-stabilized, Formvar-coated nickel grids, negatively stained using $2 \cdot 0 \%$ ammonium molybdate ( $\mathrm{pH} 5 \cdot 1)$ or $2 \cdot 0 \%$ potassium phosphotungstate ( $\mathrm{pH} 6 \cdot 0)$, and analysed in a Philips TECNAI 12 electron microscope at an operating voltage of $80 \mathrm{kV}$. Images were digitally stored and analysed using analySIS (Soft-imaging software). Images were printed after greyvalue modification.

\section{Strain ASK-1}

The $16 \mathrm{~S}$ rRNA gene sequence of strain ASK-1 was $100 \%$ similar to those of $P$. chloritidismutans DSM $13592^{\mathrm{T}}$ and $P$. stutzeri DSM 50227 (Wolterink et al., 2002). DNA-DNA hybridization between strain ASK-1 and P. chloritidismutans DSM $13592^{\mathrm{T}}$ showed $79 \%$ relatedness. To differentiate two species, DNA-DNA similarity should be less than $60-70 \%$ (Stackebrandt \& Goebel, 1994). Therefore, strain ASK-1 is identified as a strain of $P$. chloritidismutans. Both bacteria are chlorate-reducing bacteria that can only grow with oxygen and chlorate as electron acceptors. Details of utilization of electron donors and acceptors are available in Table 1. Apparently, respiration with chlorate is the only energy-yielding process under anaerobic conditions. The observed doubling times for $P$. chloritidismutans DSM $13592^{\mathrm{T}}$ and strain ASK-1 were respectively 1.5 and $10 \cdot 6 \mathrm{~h}$ when chlorate and acetate were used as electron acceptor and electron donor. Respiration with chlorate is reflected in the observed chlorate reductase activity in cell-free extracts of ASK-1 $\left(6 \cdot 1 \mathrm{U} \mathrm{mg}^{-1}\right)$. Bromate reductase activity $\left(4 \cdot 5 \mathrm{U} \mathrm{mg}^{-1}\right)$ was also found, although no growth was observed on this compound. No reductase activity was found for $\mathrm{ClO}_{4}^{-}, \mathrm{NO}_{3}^{-}$or $\mathrm{SO}_{4}^{2-}$. Similar results have been obtained for P. chloritidismutans DSM $13592^{\mathrm{T}}$, with chlorate and bromate reductase activities of 9.0 and $8.6 \mathrm{U} \mathrm{mg}^{-1}$, respectively (Wolterink et al., 2002). Despite the phylogenetic and physiological similarities, a morphological difference was seen when chlorate-grown cells were plated under aerobic conditions on nutrient agar plates. $P$. chloritidismutans DSM $13592^{\mathrm{T}}$ formed yellow-brown circular colonies and strain ASK-1 formed white circular colonies. Remarkably, a cell extract of chlorate-grown cells of $P$. chloritidismutans DSM $13592^{\mathrm{T}}$ (grown in strictly anaerobic medium) had a red-brownish colour, whereas a cell extract of chlorate-grown cells of strain ASK-1 (grown in anoxic medium) was white. This colour difference of chlorategrown cells is most likely a result of the level of haemcontaining chlorite dismutase in cell extracts, which was found to be respectively 134 and $6 \cdot 3 \mathrm{U} \mathrm{mg}^{-1}$ for $P$. chloritidismutans and strain ASK-1. Pictures of these colonies and cell extracts are available as Supplementary Fig. S1 in IJSEM Online. The strain has been deposited as P. chloritidismutans strain ASK-1 (=DSM 15671=ATCC BAA-775).

\section{Strain GR-1}

Strain GR-1 (=DSM 11199) was one of the first dissimilatory perchlorate-reducing bacteria to be described (Rikken et al., 1996); moreover, the (per)chlorate reductase

Table 1. Electron donor and acceptor usage of the chlorate-reducing bacterium strain ASK-1, P. chloritidismutans DSM $13592^{\top}$ and the perchlorate-reducing bacterium strain GR-1

For strain ASK-1, tests were performed in this study by measuring the electron acceptor concentration by HPLC. Data for P. chloritidismutans DSM $13592^{\mathrm{T}}$ were taken from Wolterink et al. (2002) and those for strain GR-1 were taken from Rikken et al. (1996).

\begin{tabular}{|c|c|c|c|}
\hline Donor/acceptor & Strain ASK-1 & P. chloritidismutans DSM $13592^{\mathrm{T}}$ & Strain GR-1 \\
\hline \multicolumn{4}{|l|}{ Electron donors } \\
\hline Utilized & $\begin{array}{l}\text { Acetate, glycerol, glycine, } \\
\text { gluconate, glucose, } \\
\text { mannitol, propionate }\end{array}$ & $\begin{array}{l}\text { Acetate, propionate, glucose, maltose, } \\
\text { gluconate, mannitol, ethanol, starch, } \\
\text { glycerol, citrate }\end{array}$ & $\begin{array}{l}\text { Acetate, propionate, caprionate, } \\
\text { malate, succinate }\end{array}$ \\
\hline Not utilized & $\begin{array}{l}\text { Arabinose, citrate, ethanol, } \\
\text { lactate, malate, maltose, } \\
\text { starch, succinate }\end{array}$ & $\begin{array}{l}\text { Malate, succinate, lactate, glycine, } \\
\text { arabinose, } \mathrm{H}_{2}\end{array}$ & $\begin{array}{l}\text { Glycine, formate, glycolate, citrate, } \\
\text { glucose, arabinose, mannose, } \\
\text { mannitol, maltose, gluconate, } \\
N \text {-acetylglucosamine, adipate, } \\
\text { phenylacetate }\end{array}$ \\
\hline \multicolumn{4}{|l|}{ Electron acceptors } \\
\hline Utilized & $\mathrm{ClO}_{3}^{-}, \mathrm{O}_{2}$ & $\mathrm{ClO}_{3}^{-}, \mathrm{O}_{2}$ & $\mathrm{ClO}_{3}^{-}, \mathrm{O}_{2}, \mathrm{ClO}_{4}^{-}, \mathrm{NO}_{3}^{-}, \mathrm{Mn}(\mathrm{IV})$ \\
\hline Not utilized & $\mathrm{ClO}_{4}^{-}, \mathrm{NO}_{3}^{-}, \mathrm{BrO}_{3}^{-}, \mathrm{SO}_{4}^{2-}$ & $\mathrm{ClO}_{4}^{-}, \mathrm{NO}_{3}^{-}, \mathrm{BrO}_{3}^{-}, \mathrm{SO}_{4}^{2-}$ & $\mathrm{BrO}_{3}^{-}, \mathrm{SO}_{4}^{2-}, \mathrm{IO}_{4}^{-}, \mathrm{SeO}_{4}^{2-}, \mathrm{Fe}(\mathrm{III})$ \\
\hline
\end{tabular}


and chlorite dismutase proteins were first purified and characterized from this strain. However, a complete taxonomic characterization of this perchlorate-reducing bacterium has not yet been done. Our data indicate that the $16 \mathrm{~S}$ rRNA gene sequence of strain GR-1 is $99 \%$ similar to that of Dechlorosoma suillum DSM $13638^{\mathrm{T}}$. DNA-DNA hybridization between these two strains revealed $85 \%$ relatedness, indicating that strain GR-1 must be identified as Dechlorosoma suillum. Interestingly, the $16 \mathrm{~S}$ rRNA gene sequences of Dechlorosoma suillum DSM $13638^{\mathrm{T}}$ (GenBank accession no. AF170348) and A. oryzae LMG 9096 (AF011347) are very similar (99.9\%), although the sequence of A. oryzae LMG $9096^{\mathrm{T}}$ was not included in the description of Dechlorosoma suillum (Achenbach et al., 2001). The $16 \mathrm{~S}$ rRNA gene sequence of A. oryzae LMG $9096^{\mathrm{T}}$ was already available in 1995 (Hurek \& Reinhold-Hurek, 1995), and the name A. oryzae was validly published in 2000 (Reinhold-Hurek \& Hurek, 2000). The DNA-DNA hybridization level of $90 \%$ between Dechlorosoma suillum DSM $13638^{\mathrm{T}}$ and A. oryzae LMG $9096^{\mathrm{T}}$ is well above the suggested limit for species identity, supporting the conclusion of Tan \& Reinhold-Hurek (2003) that Dechlorosoma suillum is a later heterotypic synonym of $A$. oryzae. Hence, we propose that strain GR-1 should be classified as a strain of A. oryzae.

A. oryzae LMG $9096^{\mathrm{T}}$ and Dechlorosoma suillum DSM $13638^{\mathrm{T}}$ share many phenotypic characteristics, including carbon source utilization preferences. Both bacteria are able to fix $\mathrm{N}_{2}$, which is a distinguishing feature of $A$. oryzae LMG $9096^{\mathrm{T}}$. A nifH homologue has been detected in both strains, and Tan \& Reinhold-Hurek (2003) observed that both can reduce acetylene $\left(\mathrm{C}_{2} \mathrm{H}_{2}\right)$ to ethylene $\left(\mathrm{C}_{2} \mathrm{H}_{4}\right)$, which confirms that the nifH gene is functional and nitrogenase is present. However, there is a key difference between these strains, the inability of A. oryzae LMG $9096^{\mathrm{T}}$ to perform dissimilatory perchlorate reduction.

Details of electron donor and acceptor usage of strain GR-1 are available in Table 1. Supplementary Fig. S2 depicts an electron micrograph of cells of strain GR-1. The cells possess a single polar flagellum and are rod-shaped with dimensions of $1 \cdot 8 \pm 0 \cdot 2 \times 0 \cdot 60 \pm 0 \cdot 05 \mu \mathrm{m}$. The micrograph reveals electron-transparent globules that vary in size and number among cells. These globules possibly contain poly- $\beta$-hydroxybutyrate or other kinds of poly- $\beta$-hydroxyalkanoates (Thalen et al., 1999). We also found strain GR-1 to have fimbriae, by which it can presumably attach itself to surfaces (data not shown).

\section{Strain MA-1 ${ }^{\top}$}

Strain MA- $1^{\mathrm{T}}$ showed $99 \cdot 9$ and $97 \cdot 6 \%$ 16S rRNA gene sequence similarity to Dechloromonas sp. strain SIUL and Dechloromonas agitata DSM $13637^{\mathrm{T}}$, respectively. The 16S rRNA gene sequence similarity between strain MA- $1^{\mathrm{T}}$ and Ferribacterium limneticum CdA- ${ }^{\mathrm{T}}$ was $97 \cdot 5 \%$. Unfortunately, this strain is not available in culture collections and therefore could not be included in further studies. DNA-DNA hybridization between Dechloromonas agitata DSM $13637^{\mathrm{T}}$ and strain MA-1 ${ }^{\mathrm{T}}$ showed only $37 \%$ relatedness, indicating that strain $\mathrm{MA}-1^{\mathrm{T}}$ represents a distinct species. The $\mathrm{G}+\mathrm{C}$ content for strain $\mathrm{MA}-\mathrm{1}^{\mathrm{T}}$ is $63.6 \mathrm{~mol} \%$, which is similar to that of Dechloromonas agitata $(63.6 \mathrm{~mol} \%)$. Based on the $16 \mathrm{~S}$ rRNA gene sequence data, strain MA $-1^{\mathrm{T}}$ resides in the Dechloromonas group (Achenbach et al., 2001), which also contains the genera Rhodocyclus and Ferribacterium. However, representatives of the latter two genera are not capable of chlorate reduction nor do they dismutate chlorite to chloride and $\mathrm{O}_{2}$. Moreover, F. limneticum is capable of $\mathrm{Fe}(\mathrm{III})$ reduction. Strain MA $-1^{\mathrm{T}}$ was not able to grow by $\mathrm{Fe}(\mathrm{III})$ reduction, similar to other chlorate-reducing bacteria (Coates et al., 1999). It has already been concluded that F. limneticum is indeed a member of a separate genus distinct from Dechloromonas (Achenbach et al., 2001). Taken together, these data imply that strain MA- $1^{\mathrm{T}}$ should be classified as a separate species within the genus Dechloromonas, and we propose the name Dechloromonas hortensis sp. nov.

Strain $\mathrm{MA}-1^{\mathrm{T}}$ was unable to grow in anoxic medium reduced with sulfide, which indicated that sulfide cannot serve as an alternative electron donor, as was described for Dechloromonas agitata DSM $13637^{\mathrm{T}}$ (Achenbach et al., 2001). Results of the physiological characterization are given in the species description. The results of a physiological comparison of the three strains described above are available in Table 2. Optimal growth of strain $\mathrm{MA}-1^{\mathrm{T}}$ was

Table 2. Characteristics of strain $\mathrm{MA}-1^{\top}$, Ferribacterium limneticum $\mathrm{CdA}-1^{\top}$ and Dechloromonas agitata DSM $13637^{\top}$

For strain MA- $1^{\mathrm{T}}$, tests were performed in this study by measuring the electron acceptor concentration by HPLC. Data for F. limneticum were taken from Cummings et al. (1999) and those for Dechloromonas agitata were taken from Achenbach et al. (2001).

\begin{tabular}{|c|c|c|c|}
\hline Characteristic & Strain MA-1 ${ }^{\mathrm{T}}$ & F. limneticum CdA-1 ${ }^{\mathrm{T}}$ & Dechloromonas agitata DSM $13637^{\mathrm{T}}$ \\
\hline Electron donors & Acetate, propionate & Acetate, formate, lactate, benzoate & $\begin{array}{l}\text { Acetate, propionate, butyrate, lactate, succinate, } \\
\text { fumarate, malate, } \mathrm{Fe}^{2+}\end{array}$ \\
\hline Electron acceptors & $\mathrm{ClO}_{4}^{-}, \mathrm{ClO}_{3}^{-}, \mathrm{O}_{2}, \mathrm{NO}_{3}^{-}$ & $\mathrm{Fe}^{3+}, \mathrm{NO}_{3}^{-}$, fumarate & $\mathrm{ClO}_{4}^{-}, \mathrm{ClO}_{3}^{-}, \mathrm{O}_{2}$ \\
\hline Source & Garden soil & Mining-impacted lake sediment & Waste pulp, sludge from pulp and paper plant \\
\hline Morphology & $\begin{array}{l}\text { Rod-shaped, single or } \\
\text { in flocs }\end{array}$ & $\begin{array}{l}\text { Straight or slightly curved, rod-shaped, } \\
\text { single or chains of two to four cells }\end{array}$ & Straight or slightly curved, rod-shaped \\
\hline
\end{tabular}


obtained at $\mathrm{pH} 7 \cdot 2$ and at a temperature of $30^{\circ} \mathrm{C}$. In cell extracts, the specific activity of chlorate reductase was $3 \cdot 12 \mathrm{U} \mathrm{mg}^{-1}$, while the chlorite dismutase had a specific activity of $155 \mathrm{U} \mathrm{mg}^{-1}$. Strain MA-1 ${ }^{\mathrm{T}}$ was isolated from a garden soil with no known history of (per)chlorate contamination. Gram-staining showed that strain MA- $1^{\mathrm{T}}$ is a Gram-negative bacterium.

\section{Description of Dechloromonas hortensis sp. nov.}

Dechloromonas hortensis (hor.ten'sis. L. fem. adj. hortensis belonging to the garden).

Gram-negative, facultatively anaerobic, motile bacterium. Colonies on (aerobic) nutrient agar plates are circular and have a yellow colour. In anoxic medium, which is not reduced with sulfide, optimal growth is obtained at $\mathrm{pH} 7 \cdot 2$ and at a temperature of $30^{\circ} \mathrm{C}$. Growth occurs with acetate and propionate as electron donors. No growth is found with citrate, gluconate, glucose, mannitol, maltose, starch, ethanol, methanol or sulfide. Perchlorate, chlorate, nitrate and oxygen are used as electron acceptors. Cell extract contains perchlorate, chlorate, nitrate and bromate reductase activities. Chlorite is converted to chloride and oxygen. The specific activity of the chlorite dismutase in cell extracts is $155 \mathrm{U} \mathrm{mg}^{-1}$. The species belongs to the 'Betaproteobacteria'. The $16 \mathrm{~S}$ rRNA gene sequence is $99.9 \%$ similar to that of Dechloromonas sp. strain SIUL. The highest similarity to a species with a validly published name is $97 \cdot 6 \%$, to Dechloromonas agitata DSM $13637^{\mathrm{T}}$. DNA-DNA hybridization between the type strain and Dechloromonas agitata DSM $13637^{\mathrm{T}}$ shows $37 \%$ relatedness. The $\mathrm{G}+\mathrm{C}$ content of the type strain is $63.6 \mathrm{~mol} \%$.

The type strain, MA- $1^{\mathrm{T}}\left(=\mathrm{DSM} 15637^{\mathrm{T}}=\right.$ ATCC BAA$776^{\mathrm{T}}$ ), was obtained from a garden soil.

\section{Acknowledgements}

We thank H. G. Trüper for advice concerning the nomenclature of strain MA- $1^{\mathrm{T}}$. This work was supported by the Earth and Life Sciences Foundation (ALW), which is subsidized by the Netherlands Organization for Scientific Research (NWO).

\section{References}

Achenbach, L. A., Michaelidou, U., Bruce, R. A., Fryman, J. \& Coates, J. D. (2001). Dechloromonas agitata gen. nov., sp. nov. and Dechlorosoma suillum gen. nov., sp. nov., two novel environmentally dominant (per)chlorate-reducing bacteria and their phylogenetic position. Int J Syst Evol Microbiol 51, 527-533.

Bradford, M. M. (1976). A rapid and sensitive method for the quantification of microgram quantities of protein utilizing the principle of protein-dye binding. Anal Biochem 72, 248-254.

Cashion, P., Holder-Franklin, M. A., McCully, J. \& Franklin, M. (1977). A rapid method for the base ratio determination of bacterial DNA. Anal Biochem 81, 461-466.

Coates, J. D. \& Achenbach, L. A. (2004). Microbial perchlorate reduction: rocket-fueled metabolism. Nat Rev Microbiol 2, 569-580.
Coates, J. D., Michaelidou, U., Bruce, R. A., O'Connor, S. M., Crespi, J. N. \& Achenbach, L. A. (1999). Ubiquity and diversity of dissimilatory (per)chlorate-reducing bacteria. Appl Environ Microbiol 65, 5234-5241.

Coyle, C. L., Zumft, W. G., Kroneck, P. M., Korner, H. \& Jakob, W. (1985). Nitrous oxide reductase from denitrifying Pseudomonas perfectomarina. Purification and properties of a novel multicopper enzyme. Eur J Biochem 153, 459-467.

Cummings, D. E., Caccavo, F., Jr, Spring, S. \& Rosenweig, R. F. (1999). Ferribacterium limneticum, gen. nov., sp. nov., an Fe(III)reducing microorganism isolated from mining-impacted freshwater lake sediments. Arch Microbiol 171, 183-188.

De Ley, L., Cattoir, H. \& Reynaerts, A. (1970). The quantitative measurement of DNA hybridization from renaturation rates. Eur J Biochem 12, 133-142.

Escara, J. F. \& Hutton, J. R. (1980). Thermal stability and renaturation of DNA in dimethyl sulfoxide solutions: acceleration of the renaturation rate. Biopolymers 19, 1315-1327.

Hungate, R. E. (1969). A roll tube method for cultivation of strict anaerobes. Methods Microbiol 3B, 117-132.

Hurek, T. \& Reinhold-Hurek, B. (1995). Identification of grassassociated and toluene-degrading diazotrophs, Azoarcus spp., by analyses of partial $16 \mathrm{~S}$ ribosomal DNA sequences. Appl Environ Microbiol 61, 2257-2261.

Huß, V. A. R., Festl, H. \& Schleifer, K. H. (1983). Studies on the spectrometric determination of DNA hybridization from renaturation rates. Syst Appl Microbiol 4, 184-192.

Jahnke, K.-D. (1992). Basic computer program for evaluation of spectroscopic DNA renaturation data from Gilford System 2600 spectrometer on a PC/XT/AT type personal computer. J Microbiol Methods 15, 61-73.

Kengen, S. W. M., Rikken, G. B., Hagen, W. R., van Ginkel, C. G. \& Stams, A. J. M. (1999). Purification and characterization of (per)chlorate reductase from the chlorate-respiring strain GR-1. J Bacteriol 181, 6706-6711.

Lovley, D. R. \& Phillips, E. J. P. (1987). Rapid assay for microbially reducible ferric iron in aquatic sediments. Appl Environ Microbiol 53, 1536-1540.

Ludwig, W. \& Strunk, O. (1996). ARB, a software environment for sequence data. http://www.arb-home.de/

Matsubara, T., Frunzke, K. \& Zumft, W. G. (1982). Modulation by copper of the products of nitrite respiration in Pseudomonas perfectomarinus. J Bacteriol 149, 816-823.

Mesbah, M., Premachandran, U. \& Whitman, W. B. (1989). Precise measurement of the $\mathrm{G}+\mathrm{C}$ content of deoxyribonucleic acid by high-performance liquid chromatography. Int J Syst Bacteriol 39, 159-167.

Plugge, C. M., Zoetendal, E. G. \& Stams, A. J. M. (2000). Caloramator coolhaasii sp. nov., a glutamate-degrading, moderately thermophilic anaerobe. Int J Syst Evol Microbiol 50, 1155-1162.

Rainey, F. A., Ward-Rainey, N., Kroppenstedt, R. M. \& Stackebrandt, E. (1996). The genus Nocardiopsis represents a phylogenetically coherent taxon and distinct actinomycete lineage: proposal of Nocardiopsaceae fam. nov. Int J Syst Bacteriol 46, 1088-1092.

Reinhold-Hurek, B. \& Hurek, T. (2000). Reassessment of the taxonomic structure of the diazotrophic genus Azoarcus sensu lato and description of three new genera and new species, Azovibrio restrictus gen. nov., sp. nov., Azospira oryzae gen. nov., sp. nov. and Azonexus fungiphilus gen. nov., sp. nov. Int J Syst Evol Microbiol 50, 649-659.

Renner, R. (1998). Perchlorate-tainted wells spur government action. Environ Sci Technol 32, 210A. 
Rikken, G. B., Kroon, A. G. M. \& van Ginkel, C. G. (1996). Transformation of (per)chlorate into chloride by a newly isolated bacterium: reduction and dismutation. Appl Microbiol Biotechnol 45, 420-426.

Scholten, J. C. M. \& Stams, A. J. M. (1995). The effect of sulfate and nitrate on methane formation in a freshwater sediment. Antonie van Leeuwenhoek 68, 309-315.

Stackebrandt, E. \& Goebel, B. M. (1994). Taxonomic note: a place for DNA-DNA reassociation and 16S rRNA sequence analysis in the present species definition in bacteriology. Int J Syst Bacteriol 44, 846-849.

Stams, A. J. M., van Dijk, J. B., Dijkema, C. \& Plugge, C. M. (1993). Growth of syntrophic propionate-oxidizing bacteria with fumarate in the absence of methanogenic bacteria. Appl Environ Microbiol 59, 1114-1119.

Stepanyuk, V. V., Smirnova, G. F., Klyushnikova, T. M., Kanyuk, N. I., Panchenko, L. P., Nogina, T. M. \& Prima, V. I. (1992). New species of the Acinetobacter genus, Acinetobacter thermotoleranticus sp. nov. Mikrobiologiia 61, 490-500 (in Russian).

Tan, Z. \& Reinhold-Hurek, B. (2003). Dechlorosoma suillum Achenbach et al. 2001 is a later subjective synonym of Azospira oryzae ReinholdHurek and Hurek 2000. Int J Syst Evol Microbiol 53, 1139-1142.

Thalen, M., van de IJsel, J., Jiskoot, W., Zomer, B., Roholl, P. J. M., de Gooijer, C., Beuvery, C. \& Tramper, J. (1999). Rational medium design for Bordetella pertussis: basic metabolism. J Biotechnol 75, 147-159.
Urbansky, E. T. (1998). Perchlorate chemistry: implications for analysis and remediation. Bioremediat J 2, 81-95.

Urbansky, E. T. (2002). Perchlorate as an environmental contaminant. Environ Sci Pollut Res Int 9, 187-192.

US Environmental Protection Agency (2000). The effect of ammonium perchlorate on thyroids. Pathology Working Group Report. Washington, DC: National Center for Environmental Assessment, US EPA. http://cfpub.epa.gov/ncea/cfm/recordisplay. cfm?deid $=15262$

van Ginkel, C. G., Plugge, C. M. \& Stroo, C. A. (1995). Reduction of chlorate with various energy substrates and inocula under anaerobic conditions. Chemosphere 31, 4057-4066.

van Ginkel, C. G., Rikken, G. B., Kroon, A. G. M. \& Kengen, S. W. M. (1996). Purification and characterization of chlorite dismutase: a novel oxygen-generating enzyme. Arch Microbiol 166, 321-326.

Wolterink, A. F. W. M., Jonker, A. B., Kengen, S. W. M. \& Stams, A. J. M. (2002). Pseudomonas chloritidismutans sp. nov., a nondenitrifying, chlorate-reducing bacterium. Int J Syst Evol Microbiol 52, 2183-2190.

Wu, J., Unz, R. F., Zhang, H. \& Logan, B. E. (2001). Persistence of perchlorate and the relative numbers of perchlorate- and chloraterespiring microorganisms in natural waters, soils, and wastewater. Bioremediat J 5, 119-130. 